\title{
Post-September 11 Regional Geopolitics: Azerbaijan and the New Security Environment in the South Caucasus
}

\author{
Elkhan Nuriyev ${ }^{1}$
}

\section{Introduction}

The September 11 terrorist attacks on the United States have seriously altered the world's geopolitics, including the regional situation in the volatile South Caucasus, where the three former Soviet republics of Armenia, Azerbaijan, and Georgia are acutely embroiled in a complex set of ethnic conflicts. In point of fact, events of recent months have indicated serious changes in the dynamics of the South Caucasus, changes that may have long-lasting implications for Azerbaijan's security and the future of the entire region. The major change is the growing importance of Azerbaijan to the United States, currently accompanied by an activation of American involvement in the region.

The conflict over Nagorno-Karabakh, which threatens Azerbaijan's security and stability, has been a crucial obstacle to the successful development of international oil contracts. ${ }^{2}$ The unresolved conflict has taken a heavy toll in terms of human lives. Many refugees still live in squalid conditions, and there is therefore growing pressure to address the problem. This increasingly complicates the peace process and results in a situation of no war, yet no peace, in the conflict-torn area.

Eleven years after the collapse of the Soviet Union, tensions between Armenia and Azerbaijan remain unabated, and there is a risk of fresh violence flaring in the region while the United States and other Western democracies have focused their attention on the anti-terrorism campaign. Geopolitical strains create new challenges and options that indicate the seriousness of the upcoming crisis in the South Caucasus. The long-term security of Azerbaijan continues to be threatened by the lack of resolution of the geopolitical stalemate over Nagorno-Karabakh.

The post-Soviet life of Azerbaijan and the other newly independent states of the South Caucasus remains critically complex. Armenia, Azerbaijan, and Georgia are in historic transition, and are no more than weak nations with fragile statehood. And therefore the post-colonial period of struggle of independence is still going on, and is likely to continue for many years.

\footnotetext{
${ }^{1}$ Dr. Elkhan Nuriyev is Director of the Center for International Studies in Baku, Azerbaijan. He is currently Alexander von Humboldt Research Fellow in the Arbeitsstelle Friedensforschung Bonn/Peace Research Center in Bonn, Federal Republic of Germany.

2 The fourteen-year-old Armenia-Azerbaijani dispute over Nagorno-Karabakh is the first serious ethnic conflict on former Soviet territory. Tensions between Armenia and Azerbaijan escalated in 1988, and full-scale war broke out in 1992. The 1994 truce ended the war in which over 30,000 people were killed.
} 
Old Problems and New Opportunities in the Context of the War Against Terrorism

After gaining independence in 1991, Azerbaijan collided with immediate internal and external challenges to its territorial integrity and sovereignty. Although the early years of the post-independence period were very difficult, Azerbaijan, under the one-year rule of the popularly elected pro-Turkish President, Ebulfez Elchibey, succeeded in getting all Russian forces and border troops withdrawn? Mr. Elchibey promised democratic reforms within the country and quick victory in Nagorno-Karabakh. However, he could not accomplish the major parts of his presidential program, and the country began to slip rapidly into political and economic chaos. As a result, Mr. Elchibey, who Azerbaijani society perceived as a very naive and inexperienced politician, was overthrown in June 1993 and was replaced by former Communist leader Heydar Aliyev. Mr. Aliyev, in turn, tried to balance the interests of the major powers to secure Azerbaijan's independence. He began to pursue a more even-handed approach in foreign policy relations with neighboring countries. Since the Aliyev presidency, Azerbaijan has come under severe pressure from Moscow to allow Russian military bases on its soil, but thus far has failed to do so. The Kremlin, using the Nagorno-Karabakh war as leverage, has heavily increased its influence in recent years with the purpose of reestablishing Russian control of the Azerbaijani-Iranian frontier by bringing back its border guards. Moscow very much hopes to benefit from the vast oil reserves of Azerbaijan, and has been forcing the Azerbaijani leadership to grant Russian corporations a greater share in Azerbaijani oil rights.

In the meantime, Azerbaijan remains very concerned about the continuing level of Russian-Armenian military cooperation. Arms transfers played a crucial role in Armenia's seizure of large areas of Azerbaijan during the war, resulting in a million refugees and internally displaced persons. Ethnic Azeris from the part of Azerbaijan under Armenian control are prevented from returning to their homes by a heavily militarized ruling structure. Such a deadlocked situation of no war, yet no peace in the area of conflict and a number of other destabilizing factors have made Azerbaijan seek outside help from both the United States and Turkey to restore a seriously violated balance of power in the region. Azerbaijan

\footnotetext{
${ }^{3}$ In Azerbaijan, it has been agreed that the early-warning "military facility" in Qabala, leased by Russia, will not qualify as an army base. Azerbaijan was, nevertheless, the first former Sovietruled republic to free its territory from Soviet military bases. In addition, Azerbaijan was the first to resist the allocation of Russian border troops and Russian peacekeeping forces.

${ }^{4}$ See Azerbaijan Human Development Report 1996, Publication of the United Nations Development Programme/UNDP, 1996, Baku Office of the United Nations. See also Chapter 8, "Displacement in the Former Soviet Region," in Mark Cutts, Sean Loughna, and Frances Nicholson, eds., The State of the World's Refugees 2000 - Fifty Years of Humanitarian Action, UNHCR (Oxford: Oxford University Press, 2000), 192-193.
} 
in recent years has signed several defense treaties with Turkey, and has started to consider the possibility of inviting NATO bases on its territory.

Accordingly, Russia and Iran have cited potential negative consequences of moving NATO bases to Azerbaijan. Both Moscow and Tehran view increasing American engagement and NATO's rapidly growing interest in the South Caucasus with suspicion. Baku, in turn, is ready to cooperate more fully with NATO and believes that, as the oil exporting infrastructure is developed, security concerns will draw Azerbaijan closer in the pursuit of true regional stability.

Strikingly, despite the strains of the fourteen-year old conflict with Armenia, which have severely disrupted the national economy, Azerbaijan in recent years has made considerable economic progress due to the signing of numerous oil contracts and development of foreign investment processes. Particular attention is due the signing of the "contract of the century" in September 1994, which enhanced Azerbaijan's role in the world and enabled the Azerbaijani leadership to provide the foundation for a Western presence in the Caspian Sea region. Correspondingly, Azerbaijan significantly contributed to the realization of such major regional projects as TRASECA, the Great Silk Road, alternative oil pipelines, and GUUAM.

However, the dynamics of the Nagorno-Karabakh conflict, domestic tensions, and growing contradictions between the ruling elite and different oppositional political parties, as well as many other geopolitical factors that have profoundly affected the direction of Azerbaijani foreign policy all continue to remain crucial for long-term stability in Azerbaijan. Moreover, the September 11 terrorist attacks in the United States dramatically altered geopolitical conditions in the South Caucasus. As a matter of fact, the U.S.-led war against terrorism in recent months has played a significant role in reshaping Azerbaijan's foreign policy.

In the new geopolitical environment in the South Caucasus, Azerbaijan is hoping to take advantage of new opportunities for cooperation with the United States. At the same time, the Azerbaijani ruling elite is very aware that Russia may be intent on reasserting its influence in the region while the United States is preoccupied with its anti-terrorism campaign. Since the tragic events of September 11, Azeri politicians have been very skeptical about the so-called rapprochement between Russia and the United States in the context of the contemporary war on terror. In point of fact, Baku is suspicious of Moscow's ostensible desire to join Washington to contribute towards maintaining stability in Central Asia and the Caucasus. Over the last several months, Moscow has been watching the increased U.S. activity in the region with the greatest anxiety. Moreover, Russia, along with China and Iran, has sought to foster the development of strategic trilateral co-

\footnotetext{
${ }^{5}$ Due to vast arms shipments from Russia to Armenia and because of broadening military cooperation between Moscow and Yerevan, Azerbaijan had to work on the possibility of creating a military alliance with Turkey. For more information, see RFE/RL Newsline, Volume 1, No. 131, Part I, October 3, 1997; Moskovskii Komsomolets, February 14, 1997.
} 


\section{THE QUARTERLY JOURNAL}

operation, while trying to keep the United States out of the Caspian Basin or at least to minimize American influence in the region. Baku is therefore engaged in a very delicate political game of balancing between regional and great powers, a game that could have profound ramifications for the development of Caspian Basin natural resources.

Azerbaijan has been an enthusiastic supporter of the U.S.-led anti-terrorism campaign, sharing intelligence and granting fly-over rights. The U.S. Congress has reciprocated by bolstering support for President Heydar Aliyev's government, in particular voting to lift trade sanctions imposed during the height of the NagornoKarabakh conflict in 1992. The lifting of sanctions will facilitate aid and trade, as well as potentially boost Azerbaijani efforts to develop its oil and gas sector.

While Azerbaijani leaders seem anxious to align themselves with the West in the hopes of reaping enormous oil and gas profits, they are taking care to assuage Russian security concerns, seeking to reassure Moscow that Baku's strategic cooperation with Washington is not a zero-sum gambit. Mr. Aliyev and other Azeri officials know that Russia retains powerful economic and political weapons that, if deployed, could hinder-or even upend-Azerbaijan's development plans. Baku's tactics seem dedicated to addressing Moscow's immediate strategic interests. Moscow, in turn, wants to resolve its Chechnya conundrum with the help of Baku, calling on the Azerbaijani government not to accept Chechen refugees and to repatriate those already in Azerbaijan.

At the same time, Russia is keen to retain a controlling influence in the competition to develop Caspian Basin natural resources. Georgia figures prominently in the potential construction of a pipeline, known as Baku-Ceyhan, which would break Russia's stranglehold on Caspian export routes. The pipeline as envisioned would take Caspian resources from Azerbaijan, via Georgia, to Turkey, bypassing Russia altogether. What is more interesting is that all of the recent and current domestic processes, including the contemporary geo-strategic situation in the South Caucasus, have made President Aliyev conclude an agreement about Azerbaijan's leasing the Gabala radar station to Russia for ten years. Russia and Azerbaijan had been haggling over a lease extension for several years. Mr. Aliyev, accommodating a long-standing Russian demand, had signaled his willingness to lease the Gabala early-warning radar station to Russia before his official visit in late January $2002 .{ }^{7}$

\footnotetext{
${ }^{6}$ During his October visit to Azerbaijan in 2001, Russian Interior Minister Boris Gryzlov particularly asserted that Chechen terrorists utilized Azerbaijan to engage in drug trafficking, and warned Azerbaijani officials about a risk of terrorist incidents being organized by Chechens residing in Azerbaijan. For more information, see Turan News Agency, October 30, 2001.

${ }^{7}$ A deal on the leasing of the Gabala radar station to Russia for ten years was signed between President Heydar Aliyev and his Russian counterpart Vladimir Putin during Mr. Aliyev's official visit to Moscow in January 2002. Also, see RFE/RL Transcaucasia Report, January 28, 2002.
} 
Meantime, the U.S.-led war on terrorism has given Azerbaijan one more chance to find its place within an inchoate geopolitical situation in the contemporary world. Since then, Azerbaijan has been at a very critical juncture of its development. Many Azeri officials are expressing growing concern at the deteriorating situation around the conflict-torn area. ${ }^{8}$ President Heydar Aliyev now faces what may be the greatest challenge of his long professional career. Mr. Aliyev is colliding with a very complicated dilemma. The Azeri President and his team are attempting to make a firm decision concerning whether to renew a war, to free the occupied lands, or to continue a search for a peaceful solution to the conflict. It is indeed a hard decision, not only for the ruling elite but also for the nation, which is still trying to preserve its newly gained independence without geopolitical interference from external forces.

Obviously, only the Nagorno-Karabakh conflict, which infringes on the strategic interests of Azerbaijan, remains a major threat to the security of the South Caucasus. If it can be resolved, the long-term prospects for oil development and safe oil transportation are promising. Otherwise, the ongoing impasse will hamper regional development and foreign investment for years to come.

\section{The Post-September 11 Era: Geopolitical Tensions and New Troubles Re- emerge}

The problem of relations between Azerbaijan and its neighboring countries gains additional importance by virtue of the current geopolitical situation in the South Caucasus. In point of fact, the contemporary situation represents an obvious challenge to the independence of Azerbaijan and, particularly, a prospective threat to the military-political security of Azerbaijan.

Azerbaijan is trying to survive in a very unfavorable geopolitical environment. Azerbaijan is surrounded by geopolitical actors on three sides whose interests are far from coincident with the interests of Azerbaijani national security. Two of them-Russia and Iran-hold effective levers of influence on Azerbaijan and can actively use them to impede natural resource development in the Caspian Basin.

Both Russia and Iran have concerns about security on their borders, and about the potential alliance of Turkey with Azerbaijan. Moscow and Tehran are deeply suspicious and resentful of U.S. and NATO "encroachments" that promote democracy and development in the South Caucasus. Paradoxically, from the early period of post-Soviet independence, Armenia enthusiastically joined the Russian-Iranian alliance, essentially to realize its territorial interests.

Nevertheless, the interests of all three geopolitical actors in the South Caucasus coincide in most of the spheres and, proceeding from the similarity of the geopolitical formulas that lay at the root of the foreign policy behavior of Russia

\footnotetext{
${ }^{8}$ Azerbaijan News Service (ANS), January 2002.
} 
and Iran, the achievement of the traditional formal compromise regarding division of the region into spheres of influence turns into a more than technical task. In such a geo-strategic situation, Turkey is the sole link for Azerbaijan to the Euro-Atlantic block. At the same time, the close geopolitical alliance between Turkey and Azerbaijan provides a fragile but vital balance of power in the South Caucasus, and prevents geopolitical isolation of the resource-rich region.

In the post-September 11 era, the geopolitical situation in the South Caucasus is, to an ever-greater degree, a reflection of military and political events in the region, which at the moment are characteristic of the instability and unpredictability of the entire post-Soviet Caucasus. As a matter of fact, since the declared anti-terrorism campaign began, Azerbaijan and Georgia have figured more prominently in the foreign policies of outside powers, which rigorously compete to extend their influence in this troubled area of the world. This, in turn, has resulted in the creation of two conflicting military and political alliances in the South Caucasus-Russia and Iran versus the United States and Turkey. The three newly independent states of Azerbaijan, Armenia, and Georgia are becoming increasingly involved in the geopolitical intrigues of the key power players?

Today, the major competing powers Russia, Iran, Turkey, and the United States are making every effort to play a more active role in the South Caucasus. They all have great concern regarding what happens in Azerbaijan and especially in the Caspian Sea region. For instance, if Russia considers the problem of an independent Azerbaijan as more an element of a complex of independent states in the entire Caucasus region, for Iran this problem takes on a somewhat different political form. The simple fact of existence of an even purely formally independent state of Azerbaijan is quite definitely (and not groundlessly) perceived as a real threat to national security of the Islamic Republic of Iran. In addition, the presence of the more than 20 million Azeris residing in Iran is the spark that is capable of blowing up the fragile powder keg that is the multinational structure of the Iranian state.

Tensions between Iran and Azerbaijan rose last year in July, with an Iranian warship threatening to fire on an Azeri oil exploration ship in a disputed sector of the Caspian Sea. Iran's air force intervention into the Caspian Basin not only served to escalate the situation but also did so much to deteriorate relations between Baku and Tehran that it nearly triggered a shooting war in the region. Since then, Iran has been very angered by its loss of influence in the Caspian Basin, and therefore Tehran has been trying to attempt to change the political and economic shape of the region. Furthermore, the current developments illustrate that the interests of Iran may be served even by the simple absorption of Azerbaijan on

\footnotetext{
${ }^{9}$ For a more detailed analysis of this issue, see Elkhan Nuriyev, "Shadow Pieces of the Caucasus Puzzle: A New Stage of the U.S.-Russian Confrontation in the Context of the War Against Terrorism,” Zerkalo/Ayna, Baku, Azerbaijan, November 2001.
} 
the part of Russia. In other words, the neutralization of the factor of independent Azerbaijan is in itself favorable to Iran, and in this connection Iran is able to make a gratuitous concession of Azerbaijan to Russia.

In the meantime, American foreign policy has thus far been grappling with some impediments arising from Russian-Iranian geopolitical maneuverings that hinder any serious U.S. activity in Azerbaijan and in the Caspian Basin. While Russia and Iran do not want to see the United States as a major arbitrator in the region, Azerbaijan and Georgia are trying to fully involve the United States in the geopolitical affairs of the South Caucasus. Washington, in turn, relying on Turkey, its NATO ally, has left these infant nations in a very complicated situation that merely results in leaving them face to face with Moscow.

Notwithstanding the increasing American involvement in the region within the context of the declared anti-terrorism campaign, Washington more frequently officially reacts rather cautiously to the growing pressure that Moscow is placing upon Azerbaijan and Georgia, the two Western-oriented states in the South Caucasus. Moreover, prospects of a quick resolution of the Nagorno-Karabakh and Abkhazian conflicts look gloomy despite international efforts to bring the warring sides to a peace agreement. Such a delicate situation, which actually freezes the conflicts and keeps geopolitical deadlock ongoing in the region, may force both Baku and Tbilisi to reconsider their foreign policy orientations and seek political support from the Kremlin for conflict resolution in the region.

As can be seen from the foregoing discussion, the stakes in the South Caucasus remain very high. Seemingly, the region's future is being decided right now. In truth, Azerbaijan's political stability, the regional security environment, and the future geopolitics of the South Caucasus, including the independence of three post-Soviet states-Azerbaijan, Armenia, and Georgia—are already at stake while the Western world is fully engaged in its anti-terrorism campaign.

\section{The Outlook for the Future}

Azerbaijan, like all other newly independent states, has made a geopolitical breakthrough in the early post-independence period. Nonetheless, time passes very quickly, and so far the conflict remains unsettled.

In the new geopolitical environment in the South Caucasus, the major challenge in the post-September 11 world will be to resolve the Armenian-Azerbaijani conflict over Nagorno-Karabakh and to move on to economic integration within the entire region. With the gradual defusing of the Nagorno-Karabakh conflict, Azerbaijan will be able to build a wider security system in the South Caucasus. If this is successful, Western business circles will regard the whole area as more attractive for an influx of capital. The alternative is too gloomy to contemplate: economic decline, poverty, and new ethnic conflicts that may further destabilize and divide the oil-rich country. 
The United Nations and OSCE have not focused enough attention on this dynamic part of the world. They should, therefore, play a more assertive role in bringing about peace and stability in the region. Most significantly, the international and European organizations should assist Azerbaijan and other former Soviet republics in the region with choosing conciliation over confrontation.

On the other hand, compromise must replace competition in the oil pipeline interests. Russia and the United States, along with their friends and allies, should make significant contributions to reducing geopolitical tensions and devise a new policy toward alleviating the security situation and decreasing the potential for confrontation. Otherwise, a more provocative South Caucasus will bring bloodshed to everyone in the region, with no clear winner.

The transitional period in post-Soviet Azerbaijan will probably continue for several years, since the process of transition from former Soviet republic to independent statehood, far from reaching the end, has rather hardly commenced. A very long and very difficult struggle seems to await the Azeri nation in its quest to establish itself as truly viable independent state.

In the context of the ongoing U.S.-led war against terrorism, more security challenges lurk on the horizon. Long-term stability in Azerbaijan and in the entire South Caucasus is, hence, crucial not only to nation-building efforts, but also to regional, European, and international security. 